\title{
Wybrane Londyńskie strategie przekształceń urbanistycznych na potrzeby mieszkalnictwa dostępnego
}

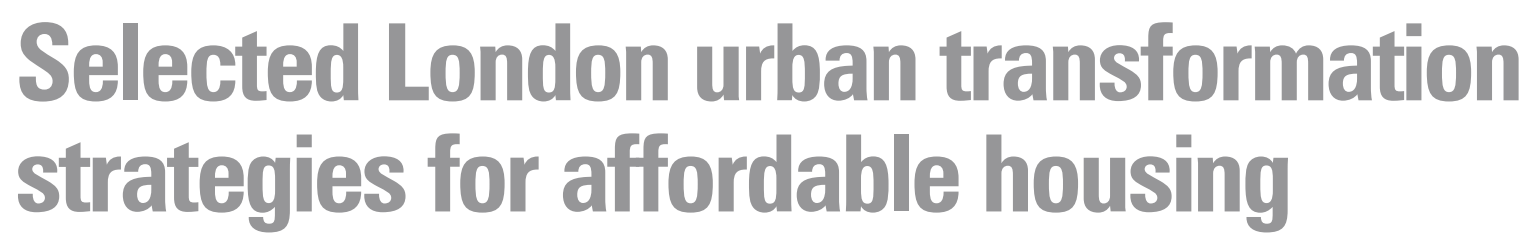

\begin{abstract}
Streszczenie
Kwestia mieszkalnictwa dostępnego cenowo (affordable housing) staje się w Europie i Polsce jednym z najistotniejszych elementów polityki społecznej i podstawowym zadaniem architektury i urbanistyki. W procesie tym jedną z kluczowych kwestii, będącą zarazem często hamulcem, jest pozyskiwanie gruntów pod takie inwestycje. Najprostszym rozwiązaniem, stosowanym obecnie w Polsce, jest budowa osiedli na peryferyjnych, niezagospodarowanych obszarach (greenfields) - jest to jednak strategia szkodliwa urbanistycznie, a długoterminowo także społecznie.

Wobec powyższego należy szukać alternatywnych wyborów lokalizacji inwestycji mieszkalnictwa dostępnego. Wiele interesujących strategii oferuje kontekst londyński, gdzie dostępność gruntów jest bardzo ograniczona. W niniejszym tekście przedstawione zostały 2 takie strategie przekształceń terenów na cele mieszkaniowe, poparte indywidualnymi studiami przypadków. Są to: (a) tereny infrastruktury technicznej, (b) ekstensywne tereny mieszkaniowe z lat 60.-70.

Każdy z przypadków został omówiony według podobnego schematu na który składa się: (a) kontekst przedsięwzięcia, (b) efekt, (c) perspektywy, (d) potencjał dla kontekstu polskiego, (e) ograniczenia w kontekście polskim. Takie ujęcie pozwoliło na zobiektywizowaną ocenę przydatności poszczególnych strategii na potrzeby polskiego mieszkalnictwa dostępnego cenowo. Jako model przekształceń o największym potencjale ilościowym uznane zostały transformacje modernistycznych osiedli blokowych, zaś scenariuszem najbardziej realistycznym uznane zostało inwestowanie na terenach infrastruktury technicznej.
\end{abstract}

\section{ABSTRACT}

The issue of affordable housing is becoming an important element of social policy in Europe and Poland and the fundamental task of architecture and urban planning. One of the key issues, which often blocks this process, is the acquisition of land for development. The simplest solution, currently employed in Poland, is the construction of housing estates in undeveloped peripheral areas, so-called greenfields. This solution, however, is detrimental to urban planning and, in the long term, also harmful to society.

Given the above, alternative locations for affordable housing development should be sought. Many interesting strategies are to be found in the context of London, where the availability of land is extremely limited. This paper presents two such land conversion strategies for housing purposes, supported by individual case studies. These concern: (a) areas of technical infrastructure, (b) extensive housing estates from the 1960s and 1970s.

Each example has been described according to a similar outline, which consists of: (a) the context of the project, (b) its effect, (c) outlook, (d) potential and limitations in the Polish context. This approach allows for an objective assessment of the suitability of individual strategies for the needs of affordable housing in Poland. As a result, transformations of existing Modernist housing estates can be considered the more promising in terms of quantity, while investing in areas of technical infrastructure seems to be the more realistic scenario. 


\section{WSTĘP - KONTEKST \\ Polska}

Kwestia mieszkalnictwa dostępnego cenowo (affordable housing) staje się w Europie i Polsce istotnym elementem polityki społecznej (Twardoch 2019) i podstawowym zadaniem architektury i urbanistyki (Tulkowska-Słyk 2019). Kluczowym problemem jest pozyskiwanie gruntów pod takie inwestycje. Najprostszym rozwiązaniem, stosowanym obecnie w Polsce, jest budowa osiedli na niezagospodarowanych obszarach peryferyjnych (Pedrycz 2017), tzw. Greenfields. Takie rozwiązanie pozwala kształtować zabudowę nieograniczoną istniejącą strukturą przestrzenną ani funkcjonalną. W ogólnym rozrachunku należy jednak przyjąć, że jest to strategia szkodliwa urbanistycznie (Twardoch 2019), a długoterminowo także społecznie (Halawa 2015).

Alternatywą jest zagospodarowanie terenów już zurbanizowanych (brownfields). Najpopularniejszymi przykładami są tu przekształcenia terenów poprzemysłowych oraz uzupełnienia istniejących kwartałów zabudowy, które w Polsce uchodzą za nowatorskie. W krajach zachodnich zostały już jednak w znacznym stopniu wyeksploatowane i konieczne stało się poszukiwanie nowych strategii.

\section{Londyn}

Awangardą rozwiązań dotyczących mieszkalnictwa dostępnego są tereny wielkomiejskie. Na tle często obserwowanych stolic europejskich, interesująco wypada przykład Londynu, który pod kątem ekonomii i kultury miejskiej koncentruje podobne cechy co Warszawa - ze znacznie większą intensywnością.

Należy zaznaczyć, że jest to przykład dwuznaczny - miasto to boryka się z dużym problemem mieszkaniowym (Edwards 2016). Stolica Zjednoczonego Królestwa charakteryzuje się szybkim wzrostem cen nieruchomości, znacznym utowarowieniem rynku mieszkaniowego, zależnością od indywidualnych kredytów hipotecznych, dużym znaczeniem prywatnego najmu połączonego ze słaba ochrona lokatorów i dominująca rolą prywatnych podmiotów w kształtowaniu rynku nieruchomości. Problemy mieszkaniowe przyczyniają się do powiększania się różnic w poziomie dochodów pomiędzy poszczególnymi grupami społecznymi (Trust for London 2013; Centre for London 2015).

Prowadzona $\mathrm{w}$ ostatnich latach polityka mieszkaniowa nie sprzyjała lokalizacji nowych zespołów zabudowy przez podmioty publiczne i organizacje pozarządowe (a jedynie przez sektor prywatny, zobowiązany realizować część mieszkań w inwestycjach jako „mieszkania dostępne cenowo", na podstawie tzw. Sekcji 106). Utrudnieniem są ceny działek osiągające w Londynie rekordowe ceny. Poza statusem jednego z głównych centrów światowej ekonomii, przyczyniał się do tego brak dostępnych gruntów, wynikający m.in. z ograniczeń konserwatorskich i przyrodniczych. Słuszna skądinąd ochrona greenfields stworzyła gigantyczna presją na tereny zurbanizowane. Najoczywistsze opcje przekształceń, takie jak tereny pofabryczne (a nawet zużyte zespoły biurowe) zostały już niemal całkowicie skonsumowane.

\section{INTRODUCTION-CONTEXT \\ Poland}

The issue of affordable housing is becoming an important element of social policy in Europe and Poland (Twardoch, 2019) and the fundamental task of architecture and urban planning (Tulkowska-Słyk, 2019). Acquiring land for such projects is a key problem. The simplest solution, currently employed in Poland, is the construction of housing estates in undeveloped peripheral areas (Pedrycz, 2017), so-called greenfields. This solution allows architects to shape buildings unconstrained by existing spatial or functional structures. Overall, however, it should be acknowledged that this is a strategy that is detrimental to urban planning (Twardoch, 2019) and, in the long term, also harmful to society (Halawa, 2015).

An alternative is development on already urbanised areas (brownfields). The most popular examples are the transformation of post-industrial areas and infills within existing urban quarters, both considered innovative strategies in Poland. In Western countries, however, they have already been largely exhausted and it has become necessary to search for new approaches.

\section{London}

Metropolitan areas are in the avant-garde of housing solutions. Among other frequently studied European capitals, the example of London is interesting, because in terms of economy and urban culture, it concentrates similar features as Warsaw-with greater intensity.

It should be noted that this is an ambiguous example-the city is facing a major housing problem (Edwards, 2016). The capital of the United Kingdom is characterised by rapidly rising property prices, a significant commodification of the housing market, dependence on individual mortgages, the large importance of private rental combined with poor tenant protection laws and the dominant role of private entities in shaping the real estate market. Housing problems contribute to the increase in differences in income levels between individual social groups (Trust for London, 2013; Centre for London, 2015).

The housing policy implemented in recent years has not favored the location of new building complexes by public entities and non-governmental organisations but only by the private sector, obliged to build some apartments as 'affordable', on the basis of Section 106 agreements. The major problem are extremely high land prices, resulting not only from London's status as one of the main centres of the world economy, but also from the lack of available land (due to environmental and conservational restrictions, etc.). The rightful protection of greenfields has created tremendous pressure on urban areas. The potential of the most obvious conversion schemes, such as the development of post-industrial areas (and even worn-out office complexes), has been almost completely consumed.

In this situation, it has become necessary to search for alternatives. This paper presents two such land conversion strategies for housing purposes, sup- 
W takiej sytuacji konieczne stało się poszukiwanie alternatyw. W niniejszym tekście przedstawione zostały 2 takie strategie przekształceń terenów na cele mieszkaniowe, poparte indywidualnymi studiami przypadków. Są to: (a) tereny infrastruktury technicznej, (b) ekstensywne osiedla mieszkaniowe z lat 60.-70.

\section{METODA BADAWCZA}

Aby przypadki móc rozpatrywać nie w sposób jednostkowy, ale jako potencjalny kierunek działania, należy je omówić w sposób uporządkowany i porównywalny. Dlatego zostały opisane według podobnego schematu, na który składa się: (a) kontekst przedsięwzięcia, (b) efekt, (c) perspektywy, (d) potencjał i ograniczenia w kontekście polskim. Części a, b i c wynikają z analizy literatury (w tym z tekstów publicystycznych oraz z rozmów z interesariuszami). Dodatkowo część b podlegała autorskiemu oglądowi. Część d jest efektem zestawienia elementów danej interwencji z najistotniejszymi składnikami kontekstu polskiego - w szczególności: potrzebami mieszkaniowymi, sytuacją demograficzną, istniejącą substancją mieszkaniową, sytuacją własnościową, uwarunkowaniami prawnymi, kulturą zamieszkiwania, praktyką inwestycyjną. Takie ujęcie pozwoliło na zobiektywizowaną ocenę przydatności poszczególnych strategii na potrzeby polskiego mieszkalnictwa dostępnego cenowo.

\section{INFRASTRUKTURA TECHNICZNA - KINGSTON HEIGHTS Kontekst}

Uzupełnieniem nieużytkowanych terenów poprzemysłowych i infrastrukturalnych są tereny wciąż funkcjonujące, które w określonych przypadkach mogą być uzupełnione o nowe funkcje. Przykładem takiej interwencji jest zespół Kingston Heights $(\mathrm{KH})$ zlokalizowany w podlondyńskiej gminie Kingston upon Thames (w ramach Greater London). Inwestycje położona jest w korzystnej lokalizacji bezpośrednio nad Tamizą i kilkaset metrów od Stacji Kolejowej (z pociągami dojeżdżającymi do centralnego Londynu w 35 minut). Do 1999 teren zajmowany był przez stację energetyczną należącą do krajowego operatora. Jego atrakcyjność zaważyła jednak na decyzji o zainwestowaniu przy zachowaniu funkcjonujące infrastruktury. Taka technicznie skomplikowana sytuacja predysponowała inwestycje do zastosowania innowacyjnego podejścia, które polegało przede wszystkim na:

- zamknięciu urządzeń energetycznych w wielkiej 4-kondygnacyjnej klatce z betonu i stali, a następnie obudowaniu jej mieszkaniami

- zróżnicowaniu standardu i funkcji (mieszkania dostępne + luksusowe apartamenty + hotel)

- nowatorskich rozwiązaniach instalacyjnych (pompa ciepła czerpiąca energię z Tamizy - pierwsze tego typu rozwiązania Anglii [Mitsubishi 2013])

Połączenie tych interwenci pozwoliło osiągnąć efekt synergii i komercyjny sukces inwestycji, mimo nakładów ok. 70M funtów.

\section{Efekt}

Złożona sytuacja przestrzenno-funkcjonalna była też wyzwaniem architektonicznym. Całość terenu podzie- ported by individual case studies. These concern: (a) areas of technical infrastructure, (b) extensive housing estates from the 1960s and1970s.

\section{RESEARCH METHOD}

To be able to consider cases not individually, but as a potential course of action, they should be discussed in an orderly and comparable manner. Therefore, they have been described according to a similar outline, which consists of: (a) the context of the project, (b) its effect, (c) outlook, (d) potential and limitations in the Polish context. Parts $\mathrm{a}, \mathrm{b}$ and $\mathrm{c}$ are the result of an analysis of the literature (including journalistic texts and conversations with stakeholders). In addition, part b was subject to the author's review. Part $d$ is the result of a comparison of the elements of a given intervention with the most important components of the Polish context-in particular: housing needs, demographic situation, existing housing infrastructure, ownership situation, legal conditions, housing culture, investment practices. This approach allows for an objectified assessment of the suitability of individual strategies for the needs of affordable housing in Poland.

\section{TECHNICAL INFRASTRUCTURE-KINGSTON HEIGHTS \\ Context}

The resource of unused post-industrial and infrastructure areas as potential sites for new development may be expanded to include still-functioning objects, which in certain cases may be supplemented with new functions. An example of such an intervention is the Kingston Heights $(\mathrm{KH})$ estate located in the Kingston upon Thames commune near London (within Greater London). The estate is located in an attractive location directly upon the Thames and a few hundred metres from the Railway Station (with trains commuting to central London in 35 minutes). Until 1999, the area was occupied by a power station belonging to the national operator. Its attractiveness, however, influenced the decision to invest in it, while maintaining the operating infrastructure. Such a technically complicated situation predisposed developers to apply an innovative approach, which mainly consisted of:

- enclosing power equipment in a large 4-storey concrete and steel block, and then building apartments around it,

- differentiating the standard and function of the new development (affordable flats + luxury apartments + hotel),

- innovative installation solutions (heat pump drawing energy from the Thames-England's first of its kind [Mitsubishi, 2013]),

The combination of these interventions made it possible to achieve a synergy effect and the commercial success of the investment, despite the expenditure of about $£ 70$ million.

\section{Effect}

The complex spatial and functional situation was also an architectural challenge. The whole area was di- 


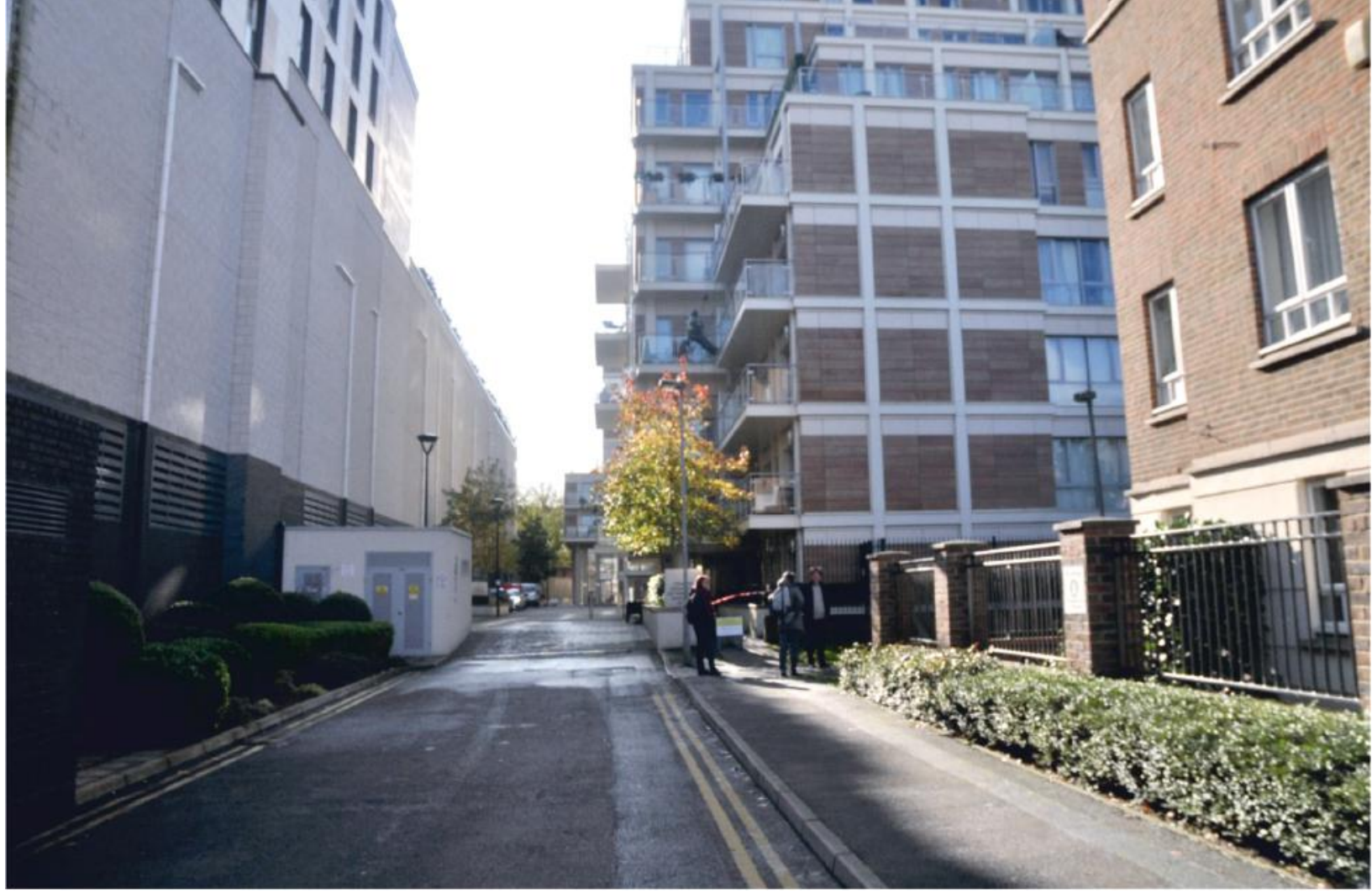

il. 1. Uliczka dzieląca dwa kwartały zabudowy - po lewej widoczna ślepa ściana klatki zamykającej infrastrukturę techniczną (od drugiej strony obudowaną mieszkaniami socjalnymi). Fot. P. Pedrycz 2019

ill. 1. A street dividing two city blocks - on the left the blank wall of the block enclosing technical infrastructure (enclosed from the other side by social housing flats). Photo by P. Pedrycz 2019

lona została na dwa podłużne kwartały - nadrzeczny oraz dalszy od rzeki, zajmowany przez infrastrukturę. Pierwszy zabudowany został apartamentowcem mieszczącym 81 luksusowych lokali schodzących tarasowo ku rzece (z 15-piętrową dominantą). Drugi, oprócz urządzeń energetycznych mieści 54 mieszkania dostępne cenowo (w tym przystosowane dla osób niepełnosprawnych) oraz 145 pokoi hotelowych. Funkcja mieszkalna obudowuje betonową klatkę stacji energetycznej na 5 najniższych kondygnacjach (mieszkania są jednostronne). Ponad klatkę wznosi się kilka kondygnacji budynku zawierających większe mieszkania, a na dachu "bunkra” znajduje się zielony taras dla gości hotelowych.

Patrząc na całokształt inwestycji i znając jej kontekst, duże wrażenie robi osiągnięty balans funkcjonalny i ekonomiczny. Rozwiązanie mieszczące różne, trudne do pogodzenia funkcje (mieszkalnictwo i infrastruktura techniczna, ale także mieszkalnictwo luksusowe i dostępne) wydaje się nie tylko bezkolizyjne, ale także synergiczne. Apartamentowiec wyzyskuje wprawdzie w całości widok na rzekę Tamizę zasłaniając go tańszym lokalom, ale jednocześnie pozwala ekonomicznie zrównoważyć kosztowną inwestycję. Przy tym, brak widoku nie czyni dostępnych apartamentów "gorszymi" - nadal znajdują się one w doskonałej lokalizacji (kilka kroków od rzeki i stacji kolejowej). Mieszkalnictwo socjalne pozwoliło wykorzystać, trudne z komercyjnego punktu widzenia, sąsiedztwo stacji energetycznej. Obecność hotelu umożliwiła użycie płytkiego jednostronnego traktu doklejonego do masywnego bunkra. Mieszkania mają dobry standard, a dzięki zastosowaniu innowacyjnej metody grzewczej, są ciepłe (co nie jest oczywiste w angielskich mieszkaniach). Z tych powodów są przez mieszkańców bardzo cenione. vided into two longitudinal urban blocks-riverside and removed from the river, the latter occupied by infrastructure. The first was built up with an apartment building housing eighty-one luxury premises descending in terraces towards the river (with a fifteenstorey dominant). The second houses, in addition to power equipment, fifty-four affordable apartments (some adapted for the disabled) and 145 hotel rooms. The residential function encloses the concrete block of the energy station on the five lowest floors (flats are single-aspect). Above the block rise several floors containing larger apartments, and on the roof of the 'bunker' there is a green terrace for hotel guests.

Looking at the overall investment and knowing its context, the functional and economic balance achieved here is very impressive. The solution with various functions that are difficult to reconcile (housing and technical infrastructure, but also luxury and affordable housing) seems not only collision-free, but also synergistic. Although the apartment building takes advantage of the entire view of the Thames River, obscuring it from cheaper flats, it also makes possible the economical balance of the entire costly project. At the same time, the lack of a view does not make the affordable apartments 'worse' - they are still in a great location (a few steps from the river and the train station). Social housing made it possible to make use of the commercially difficult proximity of a power station. The presence of the hotel made it possible to create a narrow one-sided massing attached to the massive bunker. The apartments are of a good standard, and thanks to the innovative heating method, they 


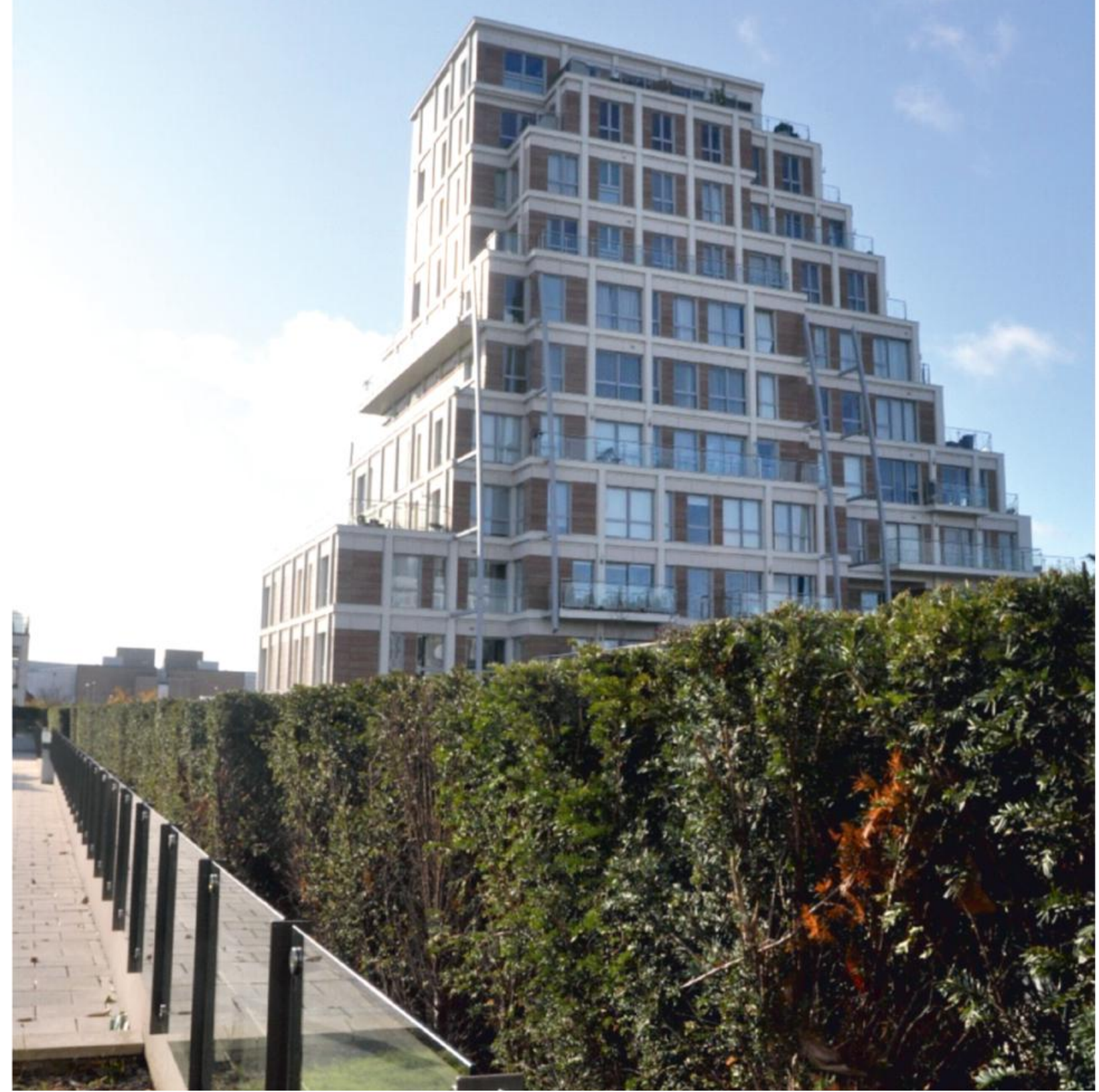

il. 2. Wieża-dominanta zawierająca tarasowo ułożone luksusowe apartamenty z widokiem na rzekę, widziana z tarasu bloku „dostępnego" zlokalizowanego na dachu obudowy urządzeń elektrycznych. Fot. P. Pedrycz 2019

ill. 2. The tower dominant comprising cascading luxury apartments with a river view, as seen from the affordable segment's roof terrace, located above the infrastructure block. Photo by Paweł Pedrycz 2019

\section{Perspektywy}

Rozpatrując przypadek KH uderzająca jest umiejętność wykorzystania atutów lokalizacji. Nie byłaby ona możliwa bez kilku kluczowych czynników:

1. Wysokich cen nieruchomości w regionie londyńskim

2. Silnej presji na wykorzystanie zurbanizowanych gruntów (brownfields)

3. Dużego doświadczenia w inwestycjach w partnerstwie publiczno-prywatnym (PPP) a także sprzyjającego otoczenia prawnego.

4.Zezwolenia na zastosowania dużej intensywności i wysokości zabudowy (znacznie przekraczających parametry w sąsiedztwie)

5.Społecznej akceptacji zamieszkiwania w nietypowym rozwiązaniu

Opisany pozytywny przykład harmonijnego funkcjonowania infrastruktury technicznej i zabudowy mieszkaniowej pokazuje, że to z pozoru wykluczające się zestawie- are warm (which is not always the case in English apartments). For these reasons, they are very much appreciated by their residents.

\section{Outlook}

Considering the case of $\mathrm{KH}$, it is striking how it gets the most out of its location. This would not be possible without several key factors:

1. High property prices in the London region,

2. Strong pressure on the use of urbanised land (brownfields),

3. Extensive experience in investments in publicprivate partnership (PPP) as well as a favourable legal environment,

4. Permits for the use of high-density and considerable height of buildings (significantly exceeding the parameters in the vicinity),

5. Social acceptance of unusual housing solutions. 
nie ma duży potencjał. W kontekście miast o znacznej intensywności jest to rozwiązanie jeszcze nie wyeksploatowane.

\section{Potencjał i ograniczenia dla kontekstu polskiego}

W kontekście polskim, o wykorzystaniu pod mieszkalnictwo terenów infrastruktury technicznej możemy mówić głównie w kontekście dużych miast, w szczególności Warszawy, która dysponuje licznymi terenami zajmowanymi przez ekstensywną infrastrukturę techniczna często w atrakcyjnych lokalizacjach. Jak wygląda zatem spełnienie warunków zdefiniowanych uprzednio jako kluczowe?

1. Wysokie ceny nieruchomości - w zestawieniu z siłą nabywczą Polaków, ceny nieruchomości w Warszawie są bardzo wysokie, warunek ten można więc uznać za spełniony

2. Presja na wykorzystanie brownfields - poza ogólnymi wskazaniami w dokumentach strategicznych brak jest realnych narzędzi sprzyjających ponownemu wykorzystaniu gruntów zurbanizowanych. W szczególności niewielka są ograniczenia (ustawowe i planistyczne) wykorzystania terenów niezurbanizowanych co powoduje, że te znacznie łatwiejsze lokalizacje są preferowane. Presja na wykorzystanie "trudnych" działek jest minimalna - warunek jest więc zdecydowanie niespełniony

3. Inwestycja w partnerstwie publiczno-prywatnym (PPP) - formuła ta w Polsce nadal jest rzadka i wiąże się z brakiem zaufania. Brak jest doświadczenia i elastyczności z obydwu stron. Także wobec poprzedniego punktu, inwestorzy prywatni nie czują potrzeby wchodzenia w partnerstwa z instytucjami publicznymi. Inwestorzy publiczni traktują developerów jak „zło konieczne” których należy kontrolować a nie współpracować. Niekorzystne są także pewne zapisy prawne - np. tzw. własność warstwowa, co utrudnia wygodne urządzenie nieruchomości. Warunek niespełniony.

4. Duża intensywność i wysokości zabudowy (przekraczająca parametry w sąsiedztwie) - w polskiej praktyce (i częściowo także teorii) urbanistycznej dąży się do wyrównywania - uśredniania zabudowy. Wysokie parametry odbierane są (częściowo słusznie) jako zaniżanie jakości przestrzeni. W efekcie polskie miasta, nawet Warszawa są zagospodarowane ekstensywnie. Warunek nie jest więc spełniony.

5. Społeczna akceptacja nietypowego rozwiązania w Polsce jest niepełna, ze względu na przyzwyczajenie społeczeństwo do ustandaryzowanych (głównie przez masowe budownictwo PRL) warunków mieszkaniowych. Homogeniczność typologiczna mieszkań jest duża, co nie sprzyja architektonicznym eksperymentom, lecz mając na uwadze skalę problemu mieszkaniowego mogłoby się okazać, że nietypowe rozwiązania mieszkaniowe zostaną zaakceptowane. Brak jednak danych by ocenić spełnienie tego kryterium.

Podsumowując należy zauważyć, że tylko jeden z warunków umożliwiających twórcze wykorzystanie terenów funkcjonującej infrastruktury technicznej na cele miesz-
The positive example of the harmonious functioning of technical infrastructure and housing in question shows that this seemingly contradictory combination has great potential. In the context of cities with significant density, this solution has not been made full use of yet.

\section{Potential and limitations for the Polish context}

In the Polish context, the use of technical infrastructure for housing can be considered mainly in the context of large cities, in particular Warsaw, which has numerous areas occupied by extensive technical infrastructureoften in attractive locations. So how does the fulfilment of the previously defined key conditions look?

1. High prices of real estate-proportionally to Poles' purchasing power, real estate prices in Warsaw are very high, so this condition can be considered fulfilled.

2. Pressure to use brownfields-apart from general indications in strategic documents, there are no real executive tools facilitating the re-use of urbanised land. In particular, there are few (statutory and planning) restrictions on the use of nonurbanised areas, which means that these much easier locations are preferred. The pressure to use 'problematic' plots is minimal-the condition is therefore definitely not met.

3. Projects executed via public-private partnership (PPP) - this formula is still rare in Poland, which results from a lack of mutual trust between actors. There is a lack of experience and flexibility on both sides. Also in view of the previous point, private developers do not feel the need to enter into partnerships with public institutions. Public developers treat their private counterparts as a 'necessary evil' that must be controlled, not collaborated with. Certain legal provisions are also unfavourable-e.g. layered ownership, which makes it difficult to conveniently arrange a property. Condition not met.

4. High density and considerable height of buildings (exceeding the parameters in the vicinity)_Polish urban practice (and partly also theory) seeks to equalise building height. High parameters are perceived (in part rightly) as a decrease in the quality of space. As a result, Polish cities, even Warsaw, are developed extensively. The condition is therefore not met.

5. Social acceptance of an atypical solution-in Poland it is incomplete due to the fact that society is used to standardised housing conditions, mainly due to the effects of mass construction in the People's Republic of Poland. The typological homogeneity of flats is high and architectural experiments are rare. But given the scale of the housing problem, it may turn out that atypical housing solutions will be accepted. However, there is no data to assess the fulfilment of this criterion.

Summing up, it should be noted that only one of the conditions enabling the creative use of areas of existing technical infrastructure for housing purposes 
kaniowe spełniony jest w polskich warunkach. Oznacza to że, mimo niewątpliwego potencjału, droga ta ma małe szanse na szybką realizację. Kluczową i prawdopodobnie pierwotną przyczyna jest brak presji na optymalne wykorzystanie gruntu. W sytuacji dużej dostępności „łatwych" przedmiejskich terenów i niewielkich ograniczeń w ich wykorzystaniu wszelkie ambitniejsze (w sensie urbanistycznym, inwestycyjnym, technicznym czy proceduralnym) metody nie są traktowane jako istotna alternatywa.

\section{EKSTENSYWNE TERENY MIESZKANIOWE Z LAT 60-70 - ROBIN HOOD GARDENS \\ Kontekst}

Możliwe do wykorzystania tereny przemysłowe i infrastrukturalne są także w Londynie stosunkowo nieliczne. Nie brakuje natomiast obszarów mieszkaniowych, których intensywność jest niska i daje możliwość dogęszczenia. Najbardziej radykalnym a zarazem skutecznym sposobem jest całkowite zastąpienie starej zabudowy nową. Tryb takiej operacji zależny jest od istniejącego zagospodarowania. Tradycyjny typ londyńskiej tkanki, zespoły domów szeregowych, który osiąga małą gęstość za sprawą niedużej wysokości, jest oporny na zmianę, co wynika ze znacznego rozdrobnienia własnościowego i dużego wskaźnika powierzchni zabudowy.

Stosunkowo łatwiej dostępne są tereny mieszkalnictwa socjalnego stworzone w latach 50., 60. i 70. Jako zespoły powstałe w okresie modernizmu, prezentują na ogół typowe cechy tamtego okresu: swobodną kompozycję, zróżnicowaną wysokość w ramach różnych typów blokowych, dużą ilość terenów otwartych.

Jednym z bardziej znanych londyńskich osiedli tego typu jest Robin Hood Gardens (RHG) zaprojektowane w późnych latach 60. i zrealizowane do 1972 roku. Jest to kluczowe dzieło Alison i Petera Smithsonów, architektów związanych z Team Ten, powstałe jako reakcja na nadmiernie uproszczone projekty w duchu CIAM, w szczególności jednostkę marsylską Le Corbusiera. Zespół składał się z dwu podłużnych bloków o wysokości 7 i 10 kondygnacji, łączących typ klatkowy i galeriowy. Ciągnące się przez całą długość budynków "ulice w powietrzu" (streets in the sky) były głównym typologicznym i architektonicznym wyróżnikiem zespołu.

W praktyce jednak rozwiązanie to nie sprawdziło się. Zamiast zamierzonego charakteru społecznego galerie stały się przestrzenią zaniedbaną i niebezpieczną. Ten mankament, w połączeniu z niekorzystnym procesem starzenia się brutalistyczne architektury i niskimi paramentami urbanistycznym, przyczynił się do decyzji o gruntownym przemodelowaniu osiedla.

\section{Efekt}

Projekt przebudowy, znany jako Blackwall Reach (BR) i przyjęty w 2012 roku po odrzuceniu starań o wpisanie zespołu na listę zabytków, zakłada całkowitą rozbiórkę istniejących budynków i zastąpienie ich współczesnymi, o odmiennej formie. Operacja odbywa się jako partnerstwo publiczno-prywatne, a realizatorem wybrane zostało Swan Housing Association. is met in Polish conditions. This means that, despite its undoubted potential, this strategy has little chance of being implemented quickly. The key and probably root cause is the lack of pressure for optimal land use. In the reality of the wide availability of 'easy' suburban areas and little restrictions in their use, any more ambitious (in terms of urban planning, development, technical or procedure) methods are not seen as a significant alternative.

\section{0s-70s EXTENSIVE RESIDENTIAL AREAS-ROBIN HOOD GARDENS \\ Context}

Operating industrial and infrastructural areas that can be infilled are also relatively few in London. On the other hand, there are residential areas with low density which give the possibility of further expansion. The most radical and effective way to do so is to completely replace the old estates with new ones. The feasibility of such an operation depends on the existing development. The traditional type of London fabric, complexes of terraced houses, which are lowdensity due to their low height, is resistant to change, which results from a significant fragmentation of ownership and a high built-up area indicator.

The areas of social housing created in the 1950s, 1960 s and 1970s are relatively easier to transform. As estates created in the Modernist era, they generally present typical features of that period: free composition, different heights within various block types, and a large number of open areas.

One of the most famous London estates of this type is Robin Hood Gardens (RHG), designed in the late 1960s and in construction until 1972. It is a key piece of work by Alison and Peter Smithson, architects associated with Team Ten, designed in response to overly simplified CIAM-style designs, most notably Le Corbusier's Marseille Unit. The complex consisted of two longitudinal blocks with a height of 7 and 10 stories, combining the staircase and gallery type. The 'streets in the sky' extending throughout the buildings were the main typological and architectural distinguishing feature of the estate.

In practice, however, this solution did not prove successful. Instead of their intended social character, galleries have become a neglected and dangerous space. This drawback, combined with the unfavourable aging process of Brutalist architecture and low urban parameters, contributed to the decision to thoroughly remodel the estate.

\section{Effect}

The reconstruction scheme, known as Blackwall Reach (BR), adopted in 2012 after the rejection of efforts to have the complex become a listed site, involves the complete demolition of existing buildings and their replacement with new ones of a different form. The operation is being carried out as a publicprivate partnership with the Swan Housing Association selected as the developer.

The transformation is taking place in stages in order to enable the relocation of residents. In the first stage, 


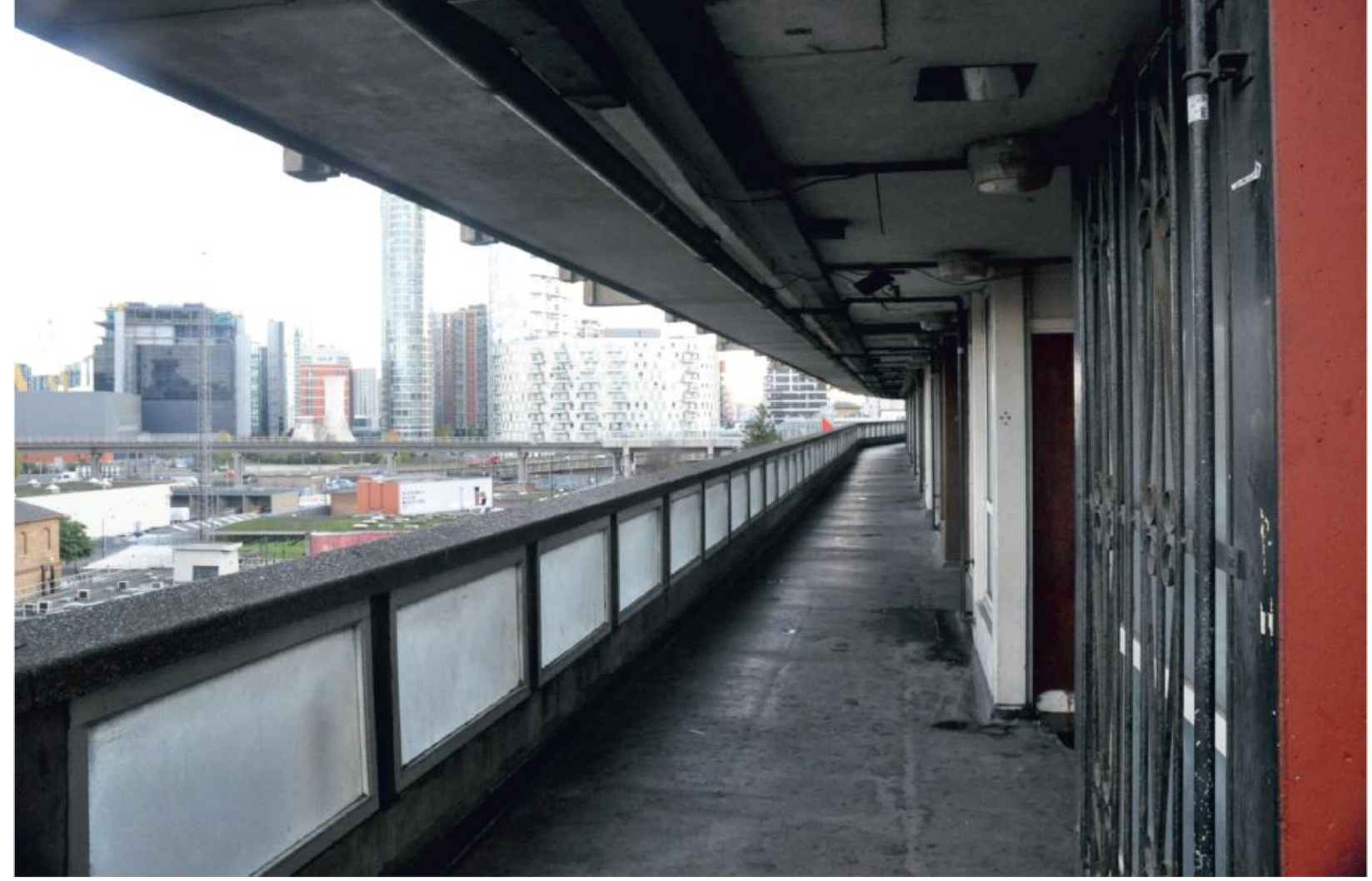

il. 3. Zaniedbana i opustoszała galeria - świadectwo niepowodzenia modernistycznej idei. Fot. P. Pedrycz 2019

ill. 3. The dilapidated and deserted gallery, a testimony to the failure of the Modernist idea. Photo by Paweł Pedrycz 2019

Transformacja odbywa się etapami, tak by umożliwić relokację mieszkańców. W pierwszym etapie wybudowane zostały obiekty na terenach północnych, niezajmowanych bezpośrednio przez bloki Robin Hood Gardens. Po częściowym ich zapełnieniu przez mieszkańców opróżnianego zachodniego bloku - został on rozebrany. Obecnie (2020), na jego miejsce stawiane są nowe obiekty o znacznej gęstości. W kolejnym etapie opróżniony zostanie, a następnie wyburzony, drugi, wschodni blok.

Zamierzenie, obecnie jest $w$ trakcie realizacji $i$ jego pełne efekty będzie można ocenić dopiero po zakończeniu i ustabilizowaniu się społeczności. W chwili obecnej analizować można parametry urbanistyczne i architektoniczne przedstawiane w projekcie.

W ramach całego przedsięwzięcia zagospodarowaniu ulegnie ok. 8ha terenu, spośród których jedynie ok 1,5ha na terenie założenia RHG. Liczba mieszkań szacowana jest na ok. 1600 , z czego ponad 600 na terenie RHG - zamiast oryginalnych 213 . Tak znaczny wzrost osiągnięty został pomimo zachowania zasadniczej części wewnętrznego terenu zielonego. Standardy bytowe nowej zabudowy diametralnie przewyższają te pierwotne co przełożyło się na zasadnicze poparcie przebudowy przez obecnych mieszkańców. Zastrzeżenia środowiska architektonicznego budzi jedynie zatarcie wyjątkowej wartości historycznej oraz artystycznej sztandarowego dzieła brytyjskiego modernizmu. Nowe obiekty prezentują standardowe rozwiązania typologiczne i niewyróżniającą się, przeciętną architekturę.

\section{Perspektywy}

Transformacja RHG / BR była możliwa dzięki następującym czynnikom:

1. Wysokie cen nieruchomości

2. Silna presja na wykorzystanie brownfields dwellings were built in the Northern areas, not directly occupied by Robin Hood Gardens blocks. After their partial filling-up by the residents of the emptied Western block, the latter was demolished. Currently (2020), new high-density buildings are being constructed on the emptied plot. In the next stage, the second, Eastern block will be emptied and then demolished.

The remodelling process is currently being implemented and it will be possible to fully assess its effects only after it is completed and the community stabilises. Currently, only the urban and architectural parameters presented in the project are available for analysis.

As a result of the entire project, approximately 8 ha of land will be developed, of which only approximately 1.5 ha on the site of the RHG establishment. The number of flats is estimated at around 1600, of which over 600 on the location of the RHG - instead of the original 213. Such a significant increase was achieved despite the preservation of the main part of the internal green area. Living standards of the new buildings are diametrically higher than the original ones, which translated into substantial support for the reconstruction scheme by current residents.

Objections from the architectural community are raised only for neglecting the exceptional historical and artistic value of a flagship work of British Modernism. The new buildings present standard typological solutions and unremarkable, average architecture.

\section{Outlook}

RHG/BR transformation was possible due to the following factors:

1. High real estate prices,

2. Strong pressure to use brownfields, 


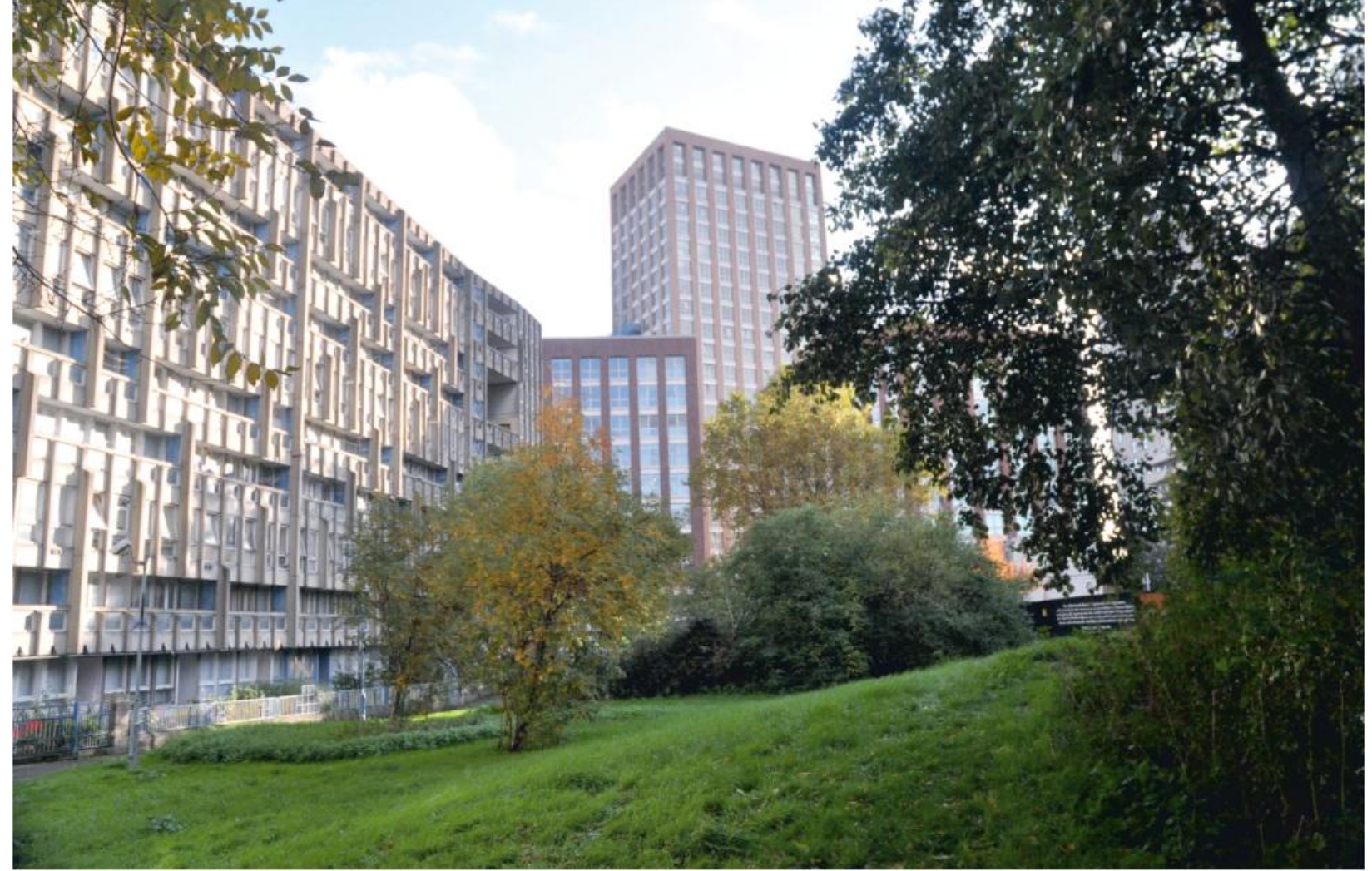

il. 4. Front istniejącego jeszcze bloku Robin Hood Gardens wraz z nową zabudową Blackwall Reach i zachowanym wewnętrznym parkiem. Fot. P. Pedrycz 2019

ill. 4. The front of the still-existing Robin Hood Gardens block along with the new development of Blackwall Reach and the preserved internal green area. Photo by Paweł Pedrycz 2019

3. Doświadczenie w inwestycjach PPP

4. Całkowita i bezpośrednia publiczna własność osiedla

5. Niskie standardy techniczne zabudowy modernistycznej. Indywidualne rozwiązania architektoniczne utrudniające podniesienie tych standardów (remonty, termomodernizację)

6. Umiarkowane podejście do kwestii ochrony dziedzictwa, w szczególności powojennego (modernizmu)

\section{Potencjał i ograniczenia dla kontekstu polskiego}

W Polsce modernistyczna zabudowa mieszkaniowa („blokowiska”) zajmuje duże obszary miast. Szacuje się, że zamieszkuje ją kilka milionów ludzi, mimo iż ich intensywność jest niewielka. Wykorzystanie tych terenów jako potencjalnego obszaru lokalizacji nowej zabudowy mieszkaniowej może mieć duży potencjał. Ich realna przydatność zależy jednak o szeregu czynników, z których pierwsze 3 zostały omówione we wcześniejszym rozdziale (stąd obecnie zostaną ujęte skrótowo):

1. Wysokie cen nieruchomości - warunek spełniony

2. Silna presja na wykorzystanie brownfields - warunek niespełniony

3. Doświadczenie w inwestycjach PPP - warunek niespełniony

4. Całkowita publiczna własność osiedla - w warunkach polskich zdecydowana większość osiedli blokowych znajduje się we władaniu Spółdzielni Mieszkaniowych. Są one podmiotami niezależnymi od miasta lub skarbu państwa. Prowadzenie przez nie skoordynowanej polityki mieszkaniowej (czy wręcz społecznej) jest trudne. Dodatkowo spółdzielnie te wywodzą się z okresu PRL i obecnie na ogół mają
3. Experience in PPP projects.

4. Total and direct public ownership of the estate,

5. Low technical standards of Modernist buildings. Individual architectural solutions that make it difficult to raise these standards (renovation, thermal retrofitting).

6. Moderate approach to the issue of heritage protection, in particular post-war (Modernism).

\section{Potential and limitations for the Polish context}

In Poland, modernist housing development ('block houses') covers large areas of cities. It is estimated that they are inhabited by few million people, although their density is low. The use of these areas as possible sites for new residential developments can have great potential. Their real usefulness, however, depends on several factors, the first 3 of which were discussed in the previous chapter (hence they will be briefly summarised now):

1. High real estate prices-this condition is fulfilled.

2. Strong pressure on the use of brownfields-unfulfilled condition.

3. Experience in PPP investments—unfulfilled condition.

4. Total public ownership of the estate-in Poland, the vast majority of block estates are owned by Housing Cooperatives. They are entities independent of the city or the state. It would be difficult for them to coordinate a common housing (perhaps even social) policy. In addition, these cooperatives originate from the Polish People's Republic period and are now generally ossified and not very dynamic. Condition not met. 
skostniałą strukturę i są mało dynamiczne. Warunek niespełniony

5. Niskie standardy techniczne zabudowy modernistycznej - w Polsce zabudowa blokowa tworzona była w standardzie, który w dalszym ciągu można uznać za spełniający wymogi współczesnego zamieszkiwania. Ponadto zastosowane rozwiązania budowlane były proste i powtarzalne (w szczególności prefabrykacja), co czyni je podatnymi na interwencje podnoszące jakość (wymiana stolarki, ocieplenie). W takiej sytuacji wyburzanie tych obiektów nie ma silnego uzasadnienia technicznego. Warunek niespełniony

6. Umiarkowane podejście do kwestii ochrony dziedzictwa, w szczególności powojennego (modernizmu) - W Polsce, ze względu na znaczne zniszczenia wojenne i małą ilość substancji historycznej, podejście to zabytków jest bardziej rygorystyczne niż w Wielkiej Brytanii. Jednak osiedla z okresu modernizmu wciąż nie są uznawane za wartościowe dziedzictwo (poza nielicznymi wyjątkami) i och transformacja prawdopodobnie byłaby możliwa. Warunek spełniony.

Jak widać, większość z powyższych warunków (4/6) jest w polskim kontekście niespełniona. Podobnie jak we wcześniejszym przykładzie, kluczowa jest kwestia braku presji na wykorzystanie terenów zurbanizowanych w sytuacji swobodnego dostępu do terenów niezurbanizowanych. Pomimo tego, powszechność występowania blokowisk, wraz z ich często korzystną lokalizacja, każą je rozpatrywać jako potencjalne tereny lokalizacji nowej zabudowy. Ze względu na czynniki techniczne i własnościowe, proces ten nie będzie przybierał formy całkowitej wymiany (jak w przypadku RHG) lecz stopniowej transformacji. Jakość tej transformacji może wahać się od spontanicznego dogęszczenia niszczącego walory oryginalnego założenia, po przemyślany proces rewitalizacji. W celu osiągnięcia optymalnego rezultatu należy zmierzyć się przede wszystkim z trudnościami własnościowymi i inwestycyjnymi - poprzez prowadzenie programu współpracy pomiędzy podmiotem publicznym (skarb państwa, miasto - oferują dotację), spółdzielczym (oferują grunty i substancję) i (być może) prywatnym (oferują sprawne zarządzanie inwestycją).

\section{PODSUMOWANIE I PERSPEKTYWY}

Powyższe zestawienie stanowiło omówienie wybranych przykładów wykorzystania na cele mieszkaniowe terenów już zagospodarowanych, które dokonane zostało w kontekście londyńskim. Wspólna, i niezwykle ważną, ich cechą jest wyjście poza oczywistą (i szeroko opisaną) strategię wykorzystania terenów poprzemysłowych. Były to kolejno: zabudowa terenów funkcjonującej infrastruktury technicznej miasta oraz wymiana stosunkowo młodej substancji mieszkaniowej na nową - znacznie intensywniejszą.

Spośród omówionych strategii obydwie uznane zostały za obiecujące w kontekście brytyjskim i jednocześnie obarczone licznymi ograniczeniami w kontekście polskim. Za podstawowy problem uznany został brak presja na ponowne wykorzystanie terenów już zurbanizowanych.
5. Low technical standards of modernist buildingsin Poland, block buildings were created in a standard that can still be considered as meeting the requirements of contemporary living. Moreover, the applied construction solutions were simple and unified (in particular, prefabrication), which makes them susceptible to interventions increasing their quality (replacement of doors and windows, insulation). In such a situation, demolishing these buildings does not have a strong technical justification. Condition not fulfilled.

6. Moderate approach to heritage protection, in particular post-war (Modernism) - in Poland, due to significant war damage and a small amount of historical substance, the approach to monuments is more stringent than in Great Britain. However, Modernist estates are still not considered a valuable heritage (with a few exceptions) and their transformation would probably be possible. Condition fulfilled.

As can be seen, most of the above conditions (4/6) are not fulfilled in the Polish context. As in the previous example, the key is the lack of pressure to use urbanised areas in a situation of free access to non-urbanized areas. Despite this, the ubiquity of block housing estates, combined with their often favourable location, allow them to be considered potential areas for the location of new buildings. Due to technical and proprietary factors, this process will not take the form of a complete replacement (as in the case of RHG) but a gradual transformation. The quality of this transformation may range from spontaneous densification with the destruction of their original beneficial qualities, to a thoughtful process of revitalisation. In order to achieve an optimal result, it is first necessary to tackle ownership and development difficulties-by running a cooperation programme between the public entity (state, city-offering subsidies), housing cooperatives (offering land and substance) and (perhaps) private developers (offering efficient management).

\section{SUMMARY AND PERSPECTIVES}

The above presentation was a discussion of selected examples of the use of already developed areas for housing purposes, which was made in the London context. Their common and extremely important feature is going beyond the obvious (and widely described) strategy of using brownfield sites. Both cases were generally successful: new development on the site of the city's existing technical infrastructure and the replacement of a relatively young housing estate with a new, much denser one.

Of the strategies discussed, both were considered promising in the British context and at the same time burdened with numerous restrictions in the Polish context. The lack of pressure on the reuse of already urbanised areas was identified as the basic problem. Despite these limitations, deep transformations of existing Modernist housing estates can be considered 
Pomimo tych ograniczeń za szczególnie obiecujące uznać można głębokie przekształcenia modernistycznych osiedli blokowych. Wymagałoby to podjęcia szeroko zakrojonych programów rewitalizacyjnych, co stanowi wyzwanie dla podmiotów publicznych (w szczególności strony rządowej i samorządowej).

\section{LITERATURA}

[1] Denison, E. (2012). The Life of the British Home: an architectural history. Wiley.

[2] Edwards, M. (2015). Future of cities: land, rent and housing in UK cities. Government Office for Science. Accessed July, 25, 2015

[3] Edwards, M. (2016). The housing crisis and London. City, 20(2), 222237.

[4] Halawa, Mateusz. (2015). In new Warsaw: Mortgage credit and the unfolding of space and time. Cultural Studies. 29. 707-732.

[5] Pedrycz, P. (2017), Modelowy dom Mieszkanie+ a wzorcowe osiedle niemieckie, w: Mieszkanie. Problem publiczny, społeczny czy prywatny? Architektoniczne uwarunkowania kształtowania społecznych zespołów mieszkaniowych w kontekście realizacji programu mieszkanie plus, praca zespołowa pod redakcją Joanny Giecewicz, Wydział Architektury Politechniki Warszawskiej

[6] Tulkowska-Słyk, K. (2019). Nowoczesne mieszkanie. Oficyna Wydawnicza Politechniki Warszawskiej.

[7] Twardoch, A. (2019). System do mieszkania. Bęc Zmiana, Warszawa.

\section{ŹRÓDŁA INTERNETOWE}

[1] Mitsubishi Electric (2013), Case study - Heating, Kingston Heights, Kingston upon Thames (data dosteppu: III 2020)

[2] O'Sullivan, F. (2020), What's Behind the Iconic Floor Plan of London, https://www.citylab.com/design/2020/01/london-architecture-history-home-design-building-floor-plan/603184/(data dostępu: III 2020) particularly promising. This would require undertaking extensive revitalisation programmes, which is a challenge for public entities (in particular the government and local authorities).

\section{REFERENCES}

[1] Denison, E. (2012). The Life of the British Home: an architectural history. Wiley.

[2] Edwards, M. (2015). Future of cities: land, rent and housing in UK cities. Government Office for Science. Accessed July, 25, 2015. [3] Edwards, M. (2016). The housing crisis and London. City, 20 (2), 222-237.

[4] Halawa, Mateusz. (2015). In new Warsaw: Mortgage credit and the unfolding of space and time. "Cultural Studies" 29. 707-732.

[5] Pedrycz, P. (2017), Modelowy dom Mieszkanie + a wzorcowe osiedle niemieckie, In: J. Giecewicz (ed.) Mieszkanie. Problem publiczny, spoteczny czy prywatny? Architektoniczne uwarunkowania kształtowania społecznych zespołów mieszkaniowych w kontekście realizacji programu mieszkanie plus, Wydział Architektury Politechniki Warszawskiej

[6] Tulkowska-Słyk, K. (2019). Nowoczesne mieszkanie. Oficyna Wydawnicza Politechniki Warszawskiej.

[7] Twardoch, A. (2019). System do mieszkania. Bęc Zmiana, Warszawa.

\section{ONLINE SOURCES}

[1] Mitsubishi Electric (2013), Case study - Heating, Kingston Heights, Kingston upon Thames (accessed on: 03.2020)

[2] O'Sullivan, F. (2020), What's Behind the Iconic Floor Plan of London, https://www.citylab.com/design/2020/01/london-architecture-history-home-design-building-floor-plan/603184/ (accessed on: 03.2020) 